\title{
Fighting against the Moral Agenda of Zapatero's Socialist Government (2004-2011): The Spanish Catholic Church as a Political Contender
}

\section{Susana Aguilar Fernández Complutense University}

\begin{abstract}
Even though not all European churches can be ascribed a political profile, moral issues have unleashed the protest of some of them alongside Christian-inspired groups and advocacy coalitions. Mobilization against these issues is not surprising in democracy but the different role that churches might play is. Unlike other European churches, the Spanish Catholic Church has acted as a political contender under Zapatero's rule (2004-2011). The new Socialist agenda, with its emphasis on morally-liberal reforms, has triggered a protest in which the church has invested significant resources and helped mobilize the more Conservative quarters of the Catholic society. This adversarial role is distinctive but not unique: the Italian and Polish churches have also opted for confrontational strategies in the face of similar challenges. However, the Spanish case is most relevant because, unlike other predominantly Catholic societies (Italy, Portugal, Ireland, and Poland), it has experienced a most profound and fastest secularization process. Confrontation can then be explained by the supply (a well-endowed Church that enjoys a privileged relationship with a non-confessional state) and not by the demand.
\end{abstract}

\section{INTRODUCTION}

Refuting Luckmann's (1973) idea that religion has become private and invisible in secularized societies; some authors have contended that certain religions have acquired a public and political profile over the last decades (Casanova 1994; Warner 2000). Resurgence has then been used to "describe either a widespread revival of religion itself or a developing context in which religion-related issues have become newly controversial

Address correspondence and reprint requests to Susanna Aguilar Fernández, Complutense University, Campus de Somosaguas, Pozuelo de Alarcón, 28023 Madrid, Spain. E-mail: susana@ ceacs.march.es 
in politics" (Madeley 2003, 2). Political visibility is mostly relevant in those Latin-American Catholic churches linked to the theology of liberation and in Conservative Evangelical churches in the USA. Unlike them, European churches on the whole can not be unequivocally ascribed a political profile. Even though "there is little evidence of a resurgence of religion as such" in Europe (Madeley 2003, 2), ethical-laden issues, such as abortion and same-sex marriage, have unleashed the protest of lay groups, advocacy coalitions, and also churches. In Spain, this type of protest has taken place under the Socialist rule of Zapatero (20042011): the Spanish Catholic Church (SCC) has been (in alliance with social and partisan forces) a significant political contender that has not simply confined itself to the dissemination of critical ideas with specific policies, like many churches have done elsewhere. It has rather aimed, first, at investing significant resources in the launching of campaigns while helping, later on, to mobilize the most Conservative sectors of society. By doing so, the SCC has contributed to creating a climate of political confrontation.

The hypothesis of this article is then that religion in European secularized societies might revert to a public status should there be religious institutions, or clerical elites, that decide to play a political role. Although clerical actors may not have been the main promoters of mobilization in Spain, they have undoubtedly backed the protest of different social groups and parties. Mobilization against ethical-laden issues is not surprising in democracy, but the role that churches might play in it is however not so easy to foresee. Unlike other European churches, the SCC has wholeheartedly played, alongside the "organized Conservative Christian society," the role of opposition force. Obviously, the reasons why certain churches decide to choose this path whereas others refrain from belligerently entering politics will be one of the main topics to be addressed. Even though exogenous reasons can be identified (e.g., the fight against growing secularization in the Western world by John Paul II and Benedict XVI), endogenous ones have to be prioritized: the deeply-rooted predominant position of the church in a society that still defines itself as mainly Catholic, and the privileged church-state relationship in a constitutionally non-confessional state, have to be borne in mind. The new Socialist agenda, which has stressed ethical and gender issues and also advocated policies that, by trying to morally compensate the victims of Francoism, have awaken memories of the past, has equally contributed to activating the protest of certain groups that react against what they perceive as a blatant attack on Christian values. When alleged 
political threats go hand in hand with a "sociological argument," whereby Spanish national identity is inextricably linked to Catholicism, the SCC finds itself legitimized to play an adversarial political role. This combination of factors can also be found in other homogeneous Catholic markets and help explain the similar confrontational position adopted by their churches (Poland and Italy). In other cases, however, contingent factors, such as the ideological proximity between the main political parties, which has prevented the awakening of religious voting (Portugal), or structural ones, such as the existence of an embedded laic tradition (France), have to be considered in order to come to terms with the more nuanced political role played by their religious institutions. Comparatively speaking, therefore, the SCC' adversarial role is distinctive but not unique: the church in Spain is one of the few European religious institutions that have opted for an open confrontational strategy when confronted with a morally-liberal agenda. However, the Spanish case is most relevant because, unlike other predominantly Catholic societies (Italy, Portugal, Ireland, and Poland), it has recently experienced a most profound and fastest secularization process (Pérez-Nievas and Cordero 2011).

The structure of this article is divided as follows: the first section helps locate the study as a supply-based one in line with religious market (or rational choice) theories; the second section offers a succinct account of the different ways in which the relationship between the church and the state is regulated in Europe, even though special emphasis is placed upon Catholic churches (CC); the specificities of the SCC will be analyzed in the next section, which will also cover not only its constitutional and fiscal status but also the contrast between its enormous resources and limited "staff"; the political activism of the SCC in the face of the "highly sensitive policies" (HSP) sponsored by the Zapatero government is the topic of the fourth section, which also compares the adversarial strategy of the church in Spain with the non-conflictive stance of other CC in Europe; the relationship between the SCC and certain social groups and political parties in the fight against HSP as well as the mobilization strategies chosen are the topics of the following section. Finally, path-dependence and contingent arguments are interwoven in the conclusions: the first ones refer to the significant weight of the SCC in a society whose cultural self-definition is predominantly Catholic and to the relative political independence of religious actors in a non-confessional state; the electoral benefits that parties may obtain if they define more clearly their religious profiles in political contexts in which different constituencies react differently to ethical-laden policies pertain to the second type of argument. 


\section{THE RELIGIOUS MARKET OR THE IMPORTANCE OF RELIGIOUSLY-INSPIRED ACTIVATORS}

In a similar way to the cleavage theory (Lipset and Rokkan 1967), the present analysis will not focus on Catholicism in Spain as a latent religious cleavage. Emphasis will be placed instead on the SCC as an interest group that might decide, given certain conditions, to activate religion politically and subsequently establish alliances with other actors in society in order to fight against certain policies. The transformation of a latent religious cleavage into a manifest one with political consequences is to be explained by the choices (the mobilization strategies) made by the activator of the cleavage (the SCC and also its allies) and by the tangible results of those choices (the creation of political confrontation).

The explanation focuses then on the supply (the supplier is the SCC) and not on the demand (Catholics may react or not to the supplier). Supply-based theories have been advocated by rational choice analysts of religion. They assume that "the public's demand for religion ... [is] constant" and aim "to rectify the neglect of the supply side in sociological analysis of religion" by drawing "attention to the work of religious leaders and activists in mobilizing resources." Rationalists have claimed that free competition in religious markets is highly desirable because "religious firms seek to maximize their profits by increasing their membership and other material resources; if there is no state regulation or state subsidy - both of which distort the market - the success of religious firms will depend on their ability to satisfy their customers." The opposite scenario, "conditions of monopoly or oligopoly, typically with state subsidies and barriers to entry, breed lazy religious institutions which lack the incentive to market their services effectively" (Norris and Inglehart 2004, 11; Aldridge 2000, 101, 103-104).

Although the basic assumption of rationalists is held to be true (i.e., religious suppliers are important and they might account for the different political salience of religion in different countries), two important disagreements need to be spelt out: (1) religion can not be considered another "typical product" in the market because "religion is for most people not a preference but an inherited social identity ... that can only be changed at a high personal cost" (Esteban 2008, 301), and (2) differences in religiosity between Europe and the United States can not be explained by the religious pluralist market prevalent in the latter.

This second point is particularly relevant because the SCC operates in a quasi-monopoly market with generous state subsidies and yet does not show the sort of "political apathy" (or laziness, as rationalists put it) 
that is frequently attached to national Protestant churches in similar market situations. Quite the contrary, religious identity can be more intense in monopolistic than plural markets and, given certain circumstances, this identity can be most easily mobilized into political action in times of crisis in non-competitive markets (Spain, Poland, Italy...).

So, if supply matters, what happens with the demand? Demand in many secularized European countries remains stubbornly stable, in the sense that most citizens still define themselves as Christians of various sorts. Yet, religious self-definition does not go hand in hand with religious practice, which is decreasing nearly everywhere: "believing without belonging is one apt way of characterizing the persistence of the sacred despite the decline of churchgoing" (Aldridge 2000, 3). If demand is stable (self-definition), if not in decline ( practice), how is it to be explained that religion has been politically activated in certain countries but not in others? The answer lies in the supply: it is the supply that fluctuates or, more specifically, the specific church operating in different countries. What type of church and religious leaders is then a crucial question to be analyzed? Yet the answer to this question needs to address, first, the regulatory context in which church-state relations takes place.

\section{CHURCH-STATE RELATIONS IN EUROPE: THE CHIMERA OF NEUTRALITY AND CATHOLIC EXCEPTIONALISM ${ }^{1}$}

"Even a cursory overview of church-state relations in contemporary Europe reveals ... a bewildering variety." Variety is the rule but the different regulatory contexts coincide in offering a so-called chimera of neutrality: "actual arrangements in Europe have deviated - and continue to deviate, some more, some less - from any feasible notion of neutrality" (Madeley 2003, 23, 4). In a simplified way, religious leadership oscillates between a-political national Protestant churches and politically-prone supranational CC. However, not all CC behave similarly: they can enjoy a quasi-monopoly religious market (Spain, Italy, Ireland, Poland) or coexist with other important denominations (The Netherlands, Belgium, Germany), the first scenario being more conducive to active political leadership. Unlike the atypical French case, in which a relatively clear-cut separation between church and state prevails, most Catholic countries can be placed in an intermediate position of partial establishment. The other extreme, with fully established churches, was until quite recently represented by Protestantism in the Nordic region but this religious 
situation has been undergoing significant changes: in Sweden church and state were separated back in 1995 and a disestablishment process is underway in Norway, whereas growing recognition of the need to disestablish the church in Denmark and Finland can also be detected. ${ }^{2}$ As Minkenberg $(2003$, 209) contends, partial establishment (which applies to all European CC except the French one) might increase the room for maneuver of religious leaders while it also proves most suitable when it comes to defending church interests. For CC the combination of partial establishment/disestablishment, monopoly in the religious market, and consolidated pastoral and social teaching paves the way to political activism. This can be transformed into a political adversarial role if another two factors concur: the existence of a national identity that has been historically and uniformly defined as Catholic, and the perception of serious threats in governments' agendas. Both factors characterize the Spanish case. As it will be later shown, CC in Spain, France, Germany, Belgium, Portugal, and Italy have therefore adopted different political roles when fighting against abortion (and same-sex marriage, in certain cases).

Even though Catholic, Orthodox, and Lutheran churches have relentlessly fought to be all-encompassing institutions along history, a "relaxation of religious monopoly regulations and the effective toleration over time of intra-confessional differences and indifferentism" has taken place in the Lutheran case. Further, "the churches of the Reformation [have been] more willing to accept the virtual privatisation of religion, thus restricting its purview to matters of personal conscience" (Madeley 2003, 38, 42). Orthodox churches, on their part, "have generally been politically passive, functioning in symbiosis with sympathetic governments." Unlike these churches, which stress "community-related issues, and tend to be less concerned with questions of individual morality ... CC, having a well-defined social teaching, pay close attention to public policy formation, especially on moral issues"3 (Enyedi 2003, 222). The $\mathrm{CC}$ expects "the secular powers to recognize it as the perfect society ... For the CC relations between religion and society [are] especially close, and [run] counter to the idea of a total separation between the two ... Catholicism is always characterized in its relation with society by its attitude of maintaining and active presence" (Madeley 2003, 42). This activism is not only to be explained by its specific social teaching but also by the role of these churches along history.

The social cleavages theory (Lipset and Rokkan 1967) has contended that $\mathrm{CC}$ can not be considered national institutions because of its allegiance to a "foreign" power: the Pope in the Vatican State. This resulted 
in a type of church that opposed the political centralization advocated mainly by anti-clerical liberal forces in the 19 century. Confrontation between liberals and the $\mathrm{CC}$ did not prevent ecclesiastical actors from shifting alliances when growingly influential Socialist and Communist parties came to represent a much more serious challenge to its power than liberals: new "friendship" between liberals and the church is best exemplified by the 1913 Gentiloni Pact in Italy. After World War II, the Vatican fought tooth and nail to promote the Christian-Democrats as a governing party in Italy whereas the $\mathrm{CC}$ in Germany, and mainly France, adopted a more cautious approach to electoral politics (Warner 2000). As a result of the Second Vatican Council, "reactive organicism," understood as the defensive and state-centered response to anti-clerical forces by $\mathrm{CC}$, seems to have become more subtle. Although CCs have never refrained from attempting to influence voting and public policy, the exercise of their political leverage has tended to be less visible. Yet it is far from true, as Casanova $(1994,62)$ contends, that "the CC everywhere has not only accepted the constitutional separation of church and state and the constitutional principle of religious freedom, but also abandoned its traditional attempts to either establish or sponsor official Catholic parties." Across post-Communist Europe, CC (and also Orthodox) churches are waging a "battle over the moral content of democracy," which embraces not only the ever thorny issues of divorce, abortion, and gay rights but also the incorporation of religion into Constitutional texts and, in some cases, the creation of confessional parties. In this battle, Poland has been so far one of the most successful cases of a "clerical democracy" (Ramet 2007, 71, 76). That is, accommodation of CC to modern political times does not usually come easy and the relationship of the church with democracy is far from being smooth. The CC still "claims that its principles are universally applicable" and considers itself "the ultimate moral authority." "Many of the Church's demands are not negotiable" and it "strives to retain control over an aspect of human beings that most interest groups have ceded to the state or to the realm of individual autonomy: values, morals, or conscience." Because of its long and deep involvement in European politics the church has an intensified "sensitivity to affronts to its perceived prerogatives." Therefore, the relationship of the CC with "democratic, secular political systems has been [and still is] troublesome" (Warner 2000, 7-8).

Despite this strained relationship, neither CC nor socially-predominant Catholic electorates have followed the same political path everywhere. The need for some historical analysis is then clear when it comes to explaining 
different church strategies and different believers' behavior in different countries and periods. "The hand of history is all too visible": the "salience and significance, as well as their precise content [of religious issues], varies enormously between ... cultural and political contexts" (Madeley 2003, 2). Or as Enyedi (2003, 220) puts it: "different starting points and different directions characterise church-state relations in Europe. Approaches that emphasise path-dependency may be particularly useful in explaining the variance." The pivotal role played by the church in Spanish history and its vast accumulation of resources over time, the embedded religious homogeneity of Spanish society, the unrivalled presence of the SCC during the long-lived Francoist dictatorship (1939-1975), as well as the gradual disentanglement from it during the early 1970s, might all have contributed to the active political role played by the SCC in democracy. It is only since the late 1970 s of the 20 century that the SCC has experienced a Copernican transformation from being, historically speaking, a state-centered established church to a society-centered (partially) disestablished church. ${ }^{4}$

\section{WHAT CHURCH? THE POLITICAL ACTIVISM OF THE SPANISH CATHOLIC CHURCH}

The SCC fights to maintain (if not enhance) its political influence in democracy by making rationally-calculated decisions that will impinge upon its existent status quo and affect its declared goals. The SCC is then analyzed as an interest group ${ }^{5}$ whom, pursuing certain objectives in a pluralist and democratic context, has different political options at its disposal: grosso modo, the church can choose between playing an active political role and abstaining from entering politics. If it chooses the first option, the SCC will probably try to find political and social allies in order to increase its probabilities of success. However, playing a political role is not without its problems: presently, "while states are expected to be religiously neutral, churches are expected to be politically impartial. Although it is rare for religious officials to be constrained in their political activity by law, direct partisan agitation is often seen as incompatible with democratic functioning" (Enyedi 2003, 227).

Even though official endorsement of a particular party by the church in democracy has not occurred, the SCC has never abstained from transmitting political recommendations to the Catholic electorate. When governments showed a conciliatory stance in relation to the SCC status quo, as 
it happened during the early phase of transition to democracy (1976-1982), the church adopted a relatively low political profile. The choice of a high political profile, which translates into an adversarial strategy, has taken place whenever the church has perceived, at specific junctures, that its vital interests were being jeopardized by particular governments. However, lack of explicit partisan support is not the same as "partisan indifferentism": as early as 1977 the Spanish Episcopal Conference (SEC) issued a document entitled, "The Moral Responsibility of the Vote," that could be interpreted as an attack on left-wing parties. Having different political formations at its disposal, the SCC decided eventually to un-officially back the Unión de Centro Democrático (Democratic Centre-UCD) (a centrist party with best winning chances) in the first 1977 democratic elections. "The electoral triumph of UCD [in 1977] meant ... the failure of Christian democracy (CD) in Spain": none of the national $\mathrm{CD}$ parties obtained any representation and some of their leaders joined later the UCD and took ministerial portfolios during the two Centrist governments (1977-1979/1979-1982) (Huneeus 1985, 176-184). Only one national party that also claimed a Christian orientation, Alianza Popular (re-founded as the Popular Party - PP in 1989), survived the CD debacle. Once the UCD lost power to the Partido Socialista Obrero Español (Spanish Socialist Workers' PartyPSOE) in 1982, the SCC was left without an important political ally.

\subsection{The SCC as a Peculiar Interest Group}

Interest groups have been defined "as organizations that are not part of the government they are trying to influence" and "as the representatives of particular subgroups in society that then link with political parties to be represented in the policy process" (Berry 1997, 4-5; Warner 2000, 18). Although the $\mathrm{CC}$ is an interest group, it is undoubtedly a very peculiar one because of its troublesome relationship with democracy. Further, the $\mathrm{CC}$ can not unmistakably be considered part of the civil society because it is not, strictly speaking, a voluntary association: in most cases, church membership is not the result of an individual decision but a family decision whereby future members are baptized long before they can express their views on the matter. The mechanisms of exit and voice are poorly contemplated by the $\mathrm{CC}$ as well: not only does the church raise all types of obstacles when people decide to opt out, but it also discourages open debate and dissent within its rank-and-file (evidently, this 
last point does not only apply to the Church but also to other hierarchical groups such as parties and unions). Instead of understanding democracy as a political mechanism of negotiation, the $\mathrm{CC}$ tends to perceive politics as a zero-sum game. This perception can be explained by the non-accommodating stance of the church in the defence of some of its morallydefined most precious goals (HSP) and by the very non-divisible nature of these goals: the pro-life (total rejection of any type of abortion) and pro-family (total rejection of marriage between same-sex people) "crusades." Perception of democracy as a zero-sum game might be more deeply entrenched in the case of the SCC because of its shorter (comparatively speaking) experience with democratic politics.

From an organizational perspective, the main actor in the SCC is the SEC, set up in 1966 following the Second Vatican Council document, Christus Dominus, that "mandates the establishment of national and regional Episcopal conferences" (Casanova 1994, 73). The SEC conforms a "permanent institution integrated by Spanish bishops who, in accordance with the Pope, carry out the pastoral functions of the Spanish Episcopate" (Statutes, Article 1.1). The 1979 agreement between the Spanish State and the Vatican recognized the civil juridical personality of the SEC (Article 1.3). ${ }^{6}$ As such, the SEC has a close relationship with the official representative of the Vatican in Spain (Nunciatura Apostólica) and has become the official speaker of the SCC with the state. It is through the coordinated and formal structure of the SEC that the SCC has evolved into a modern interest group: "previously, the church hierarchy constituted a (relatively) unshaped mass - unorganized, non-institutionalized — and exogenously controlled" (Pérez-Agote 2008b, 88, 124). ${ }^{7}$

Despite its political importance, the SEC is a collective actor that can not impose its views on its constituent members, the bishops, who are autonomous in their respective parishes (in a number of 67). Nor can the SEC force religious congregations to subscribe to their official statements: many of these congregations, working in health and educational centers, have financial agreements with state institutions and regional governments, this endangering their "loyalty" to the SEC. As far as abortion and same-sex marriage reforms are concerned, no meetings between the SEC and the government have occurred. This lack of contact contrasts vividly with intense negotiations between the same two actors when educational reforms were announced during the first mandate of Zapatero, something that seems to confirm a well-established idea whereby the main political priority of the SCC is education (Pérez-Agote and Santiago 2005; Barreiro 2000). 


\subsection{Constitutional and Fiscal Status of the SCC: A Privileged Situation}

SCC reluctance to total and unequivocal disestablishment has permeated the 1978 Constitution: during the constitutional debate the Church made it clear that it rejected the American way of church-state separation (Anderson 2003, 140). Accordingly, Spain is a non-confessional state ("no denomination will have a state character," Article 16.3), a term that intends to draw a middle line in between laic countries and confessional countries of various sorts. Likewise, "non-confessionalism" aspires to overcome the contrast between a laic state (the Second Republic 1931-1936) and a confessional one (Francoism 1939-1776) in Spanish history. Despite the fact that the Constitutional Court has often used the term "positive laicism" to refer to the religious situation, the Spanish state is not laic because the CC enjoys a privileged status. In terms of religious freedom, for instance, the Constitution implicitly recognizes the sociological fact that most Spanish people are Catholic ("public powers will take into account the religious beliefs of Spanish society") and commands public authorities to maintain "the corresponding relations of cooperation with the $\mathrm{CC}$ and the rest of the denominations" (Article 16.3). In the same line, the separation of state and church is not to be understood as religious neutrality, for the 1979 agreement between the Spanish State and the Vatican envisages, among other things, that the SCC will not be subject to state legislation on associations, religious marriage will be given civil validity and that religious assistance in hospitals, prisons and other facilities will be granted.

In terms of its financing, the SCC has been the only denomination that has received state economic support ever since democracy was restored. Since 1979, this support has emanated from the agreement between the Spanish state and the Vatican, which contemplated three different financial models to be applied during transitory periods until self-finance by the church could be attained: budget assignment, a mixed system of budget assignment and fiscal provision (money voluntarily given by taxpayers out of their tax statement) and, finally and exclusively, fiscal provision. At present, the financing system contains elements from the three different models because self-finance has not been achieved yet. In order to increase the money coming from fiscal provision (the third financing model that started out in 1987), the SCC initiated a campaign in 2007 (worthy 2.7 million $€$ ) that has resulted in a growth of taxpayers that have decided to donate money to the church: from 6,400,00 in 2006 to 7,200,000 in 2008 (around 34.1\%). 


\subsection{The Contrast between Enormous Resources and Limited Staff}

The SCC is a most astounding interest group in terms of the resources and assets at its disposal. Not only does the SCC control valueless artistic and historic heritage but it also contains over 40,000 institutions that can be broken down as follows 8 : 22,700 parishes; 906 monasteries and religious congregations; 13,000 confraternities, foundations and NGOs; 235 hospitals and health centers (attending 1,237,084 people); 876 houses for elderly and disabled people (57,653); 937 orphanages (10,835); 321 nurseries $(10,607)$; 365 special education centers $(53,140)$; 144 social centers (324,377); 305 centers for the defence of life and the family $(79,868) ; 155$ prison-related centers (45,000); 54 centers for drug-addict attention and 24 for VHI care; 5,000 schools (1,741,697 students) and 200 universities. $^{9}$

COPE is an acronym for Network of Spanish Popular Waves and is made up of a conglomerate of mass media enterprises in which the CEE owns $51.05 \%$ of the shares and the Dioceses $21.14 \%$. As a shareholder group the CEE participates $51.1 \%$ of the COPE radio station and owns $67.1 \%$ of the Popular television channel - comparatively speaking, the radio station is most successful, being third in audience $(737,000$ daily) according to the 2009 Media General Survey (Vidal Bonifaz 2010).

However, the contrast between impressive resources and "undernourished personnel" in the SCC is equally astounding. The church contains 20,000 priests (a ratio of one priest per 2,000 inhabitants) ${ }^{10}$ and merely around 1,200 seminaries: over the last two decades this number has gone down from 2,000 to 1,200 , while priest recruitment has also been falling around 30\% since 1990 (www.eldiariomontanes.es). More eloquently, in a study financed by the Catholic Santa María Foundation, entitled Youth and Religion 2000, youngsters were asked about the social utility of 13 different jobs and placed that of priesthood in the 12 th position, while only $0.7 \%$ acknowledged the possibility of ever embracing it (www.pastoral-vocacional.org; Fundación Santa María 2000).

\subsection{Cultural Catholicism in a Secularized Society}

In spite of the historical pervasiveness and impressive presence of the CC in Spanish society, Spaniards are (like most Europeans) being increasingly secularized. The main difference between the two groups is that secularization has occurred later and at a much faster pace in Spain: "between 
1981 and 1990, the collapse of religious practice has been stronger than anywhere else, and the same has happened with priest recruitment" (Davie, in Pérez-Agote, 2008b, 177). In 2004, 26.6\% declared not to belong to any religion (compared to 21.7 in 2002) while 68.9\% expressed a Catholic identity (75.4\% in 2002) (European Social Survey 2004). On a scale of 0 (non-religious) to 10 (very religious), the average Spaniard can be located roughly in the middle (5.3). More than half of the Catholic population never go to church - in slightly more than two decades almost 20\% more Catholics have stopped going to church altogether [and] those who go every Sunday did not reach a fifth ... in 2008, when in 1985 they were over a fourth" (Martín and Tsirbas 2009, 15). Religion has lost relevance in peoples' lives (out of 10, from 6.11 in 1987 to 5.34 in 2002) and is less important than health, family, work, friends, and economic well-being (only politics is placed under religion) (Santiago García 2008, 209). Less than 50\% of Spanish people place any type of trust in the SCC - a percentage that is below the European average (González-Aneo 2008, 62-3, 8; Elzo 2008, 82, 85). Most Spaniards think that the SCC has too much power and only $9 \%$ consider that it has too little or insignificant power (Pérez-Agote and Santiago $2005,120)$. Further, a great majority does not accept religious interference in electoral choices: in 2002, 82.3\% agreed that religious authorities should not try to influence peoples' voting and $81.1 \%$ expressed the same view when asked if religious authorities should not try to influence governments' decisions (Santiago García 2008, 212). Equally relevant is the fact that opinion polls show outstanding tolerance about those topics encapsulated by HSP. In a recent survey by the Sociological Research Centre, CIS ( $\left.{ }^{\circ} 2752,2008\right), 60 \%, 62.1 \%$, and $51.7 \%$ of the respondents were against the SCC stance on abortion, same-sex marriage, and the adoption of children by gay couples, respectively. The prevalence of "liberal" approaches to moral issues is most extraordinary in the face of the existence of $95.1 \%$ Spaniards above 18 who in 2002 affirmed to have had a Catholic upbringing (Santiago García 2008, 213).

\section{CHURCH ACTIVISM AND THE HIGHLY SENSITIVE POLICIES}

Since the SCC is an interest group that makes decisions that impinge upon its existent status quo and affect its declared goals, these decisions will be analyzed in relation to two HSP. These policies have something in common: the SCC perceives in them the undisputable need to "contest 
the absolute lawful autonomy of the secular spheres and their claims to be organized... without regard to extraneous ethical or moral considerations" (Casanova 1994, 57-58). HSP, understood as normative challenges, are associated with strong intensities of preference on the part of certain lay Catholic groups, and refer to (1) the defence of a family model in which a woman and a man commit themselves, through the sacred institution of marriage, to a life-long relationship and to the upbringing of children in accordance with Christian values; and (2) the defence of life, from the very first beginning of the coming into existence of the embryo to the final breath of the individual.

The first goal has antagonized the SCC to the Zapatero Presidency because the PSOE approved a same-sex marriage reform in June 2005. The second one has recently increased political tension on account of a new abortion law eventually passed in December 2009. The SCC might then have decided to embark upon a contentious political course because four different circumstances have concurred: (1) the existence of a perceived threat that derives from the government approval of "HSP"; (2) the existence of a quasi-monopoly religious market that facilitates the framing of the church demands in terms of "the Institution that defends the moral values of the broad majority of Spaniards," who are either Catholic by baptism or define themselves as Catholics; (3) the existence of well-established alliances with certain social groups; and (4) the capacity to find political allies in the fight against those HSP. ${ }^{11}$

The choice of a particular course of action by an interest group has to do with internal and external factors. Political opportunities, or the perceived existence of a favorable political situation, pertain to the second type of factor. The availability of (or absence thereof) resources is an internal factor for the undertaking, or not, of collective action: to put it succinctly, if an interest group considers itself strong enough to exert its leverage and attain its declared goals in the public sphere with some degree of success, it might rationally decide to mobilize its resources regardless of the particular political context. Alongside impressive resources, the practical absence of competing religions and the relative autonomy of the church in relation to the state have to be borne in mind when accounting for the political activism of the SCC. Further, secularization is perfectly compatible with the existence of social sectors that, opposing to this trend, undertake an intense political activity in ethical-related issues; this activity has been encouraged by the SCC, which perceives itself as being endowed with important resources of various sorts and as the institution 'representing' the majority of Spaniards who are (nominally) Catholic. Other 
contingent factors, such as the existence of "elites who aspire to obtain electoral benefits by calling upon the religious identities of voters" have to be considered as well. The level of religiosity is not changing, it is the use that ecclesiastical (and political) leaders are doing of religion what can explain the resurgence of religious voting since the 1990s. Further, this type of voting is more easily detected in Conservative voters because their "religious profile is more defined than that of Socialist supporters" ... on the left, "ideology compensates for the negative effect of religiosity, so that even those leftist voters who exhibit a high degree of church attendance are the most likely ones to vote for the PSOE" (Calvo, Martínez, and Montero 2010, 4, 28, 36).

\subsection{Political Activism: The Only Logical Course of Action?}

In vivid contrast with other churches, the SCC has explicitly adopted a belligerent political role in the fight against abortion and same-sex marriage. Unlike many European churches, which have operated as public institutions rather than as interest groups, the SCC has clearly chosen the second role. In the case of abortion protest, for instance, the main protagonist has not been the church but certain political alliances (Prolife Alliance in Great Britain), advocacy coalitions of lawyers and physicians (in France), and social groups unconnected to the religious hierarchy (Germany) (Minkenberg 2003). In the last two countries, the CC has either played a marginal role (France) or has opted for a "conciliatory" strategy in the protest (Germany): abortion liberalization in 1992 placed the German CC in an uneasy position because it officially rejected the reform but did not want to lose public money for counseling pregnant women. The resulting conflict between the Holy See and the church led to a "national approach and the let down of the Vatican" (Minkenberg 2003, 212). In Belgium, the $\mathrm{CC}$ has objected to political reforms similar to those passed in Spain, but it has not chosen a conflictive mobilization strategy: its political allies (the Christian-Democrats) have voted against these reforms in the Parliament but both, the party and the church, have refrained themselves from stirring up their social bases into political action (Botterman and Hooghe 2009). Portugal might be an equally interesting case: even though Portuguese society is more religious than the Spanish one ( $86 \%$ as compared to $75 \%$ declare to belong to the $\mathrm{CC}$ ), religious voting, in the face of ethical issues such as the legalization of abortion, is in a state of slumber because the "party system, 
revolving around two main centrist parties which are very similar in a number of ideological issues," does not offer political elites the necessary incentives to play the religious card (Montero, Calvo, and Martínez 2008, 21). In Italy, however, the referendum on abortion in the 1980s did oppose the CD party to other political formations. Further, the disappearance of the CD in 1993 has been flanked by increasing conflicts around religious and moral issues: "the Italian Bishops Conference has growingly participated in the political realm," guiding Catholic voters in terms of what to vote (as it happened in the 2005 referendum which set to repeal the Berlusconi law that prohibited in vitro fertilization) and supporting demonstrations by Catholic organizations (as the one opposed to the Prodi government's proposal to legalize homosexual unions) (Rinaldi, Segatti, and Vezzoni 2010,2). The Polish church has also moved along conflictive lines: it "wanted the constitution to codify religious foundations for state law on a number of moral issues" so that, among other things, "a constitutional ban on abortion" could be incorporated (Byrnes 2006, 107). Most worryingly, however, has been its success in terms of the "introduction of Catholic-only religious instruction in public schools ... and its involvement with the homophobic League of Polish Families" (Ramet 2007, 75). Similarly to the Italian and Polish cases, the national identity in Spain has also been historically defined as Catholic while perceived threats in governments' agendas have activated the adversarial role of a nonetheless politically-prone church. "In most Western European countries, Catholic antiabortion groups only have a narrow base of support, given the fall in religious practice. It is therefore often in combination with other groups ... that they can achieve any influence" (Parkes 1999, 288). This is also the case in Spain where non-confessional (although heavily Christian, if not Catholic-inspired) lay social groups and, to a lesser extent, conservative parties have played the main role in the protest. Thus, the crucial difference lies in the different stance, explicitly and politically antagonist, adopted by the SCC.

\subsection{Social Alliances: The Catholic Lay Movement}

Quite recently, "social movements have appeared which are either religious in nature or are challenging in the name of religion the legitimacy and autonomy of the primary secular spheres, the state and the market economy" (Casanova 1994, 5). These movements have been mobilized in Spain to protest against HSP. Although differences among the groups that 
pertain to them can be detected, they all show some common features: they are predominantly participated by the youth; they are lay (although some have created priest-based units); they usually contain a spiritual and nonsocial orientation, are traditional and non-inclusive; and they tend to prioritize the staging of big demonstrations as compared to other more conventional lobbying techniques. Equally important is their a-critical stance in relation to the SEC dictates: these organizations have backed the Church campaigns by different means (giving them publicity on their web pages, supporting the Church objectives in press conferences ...) and their leaders have sometimes marched hand in hand with Catholic elites (and certain political representatives) against HSP. Obedience to the SEC can be explained, among other reasons, by the likelihood that people participating in these organizations are those who show highest church attendance: since going to mass in Spain has been in decline over the last decades, the remaining church-goers are bound to be most exposed to the official discourse of the SCC hierarchy and, therefore, behave as the most staunch supporters of the adversarial strategy chosen by the church. Likewise, since 1996 most religious voters have gradually moved toward the right and presently support the PP (Calvo, Martínez, and Montero 2010). Differences within lay Catholic and Christian-oriented groups have to do with: (1) time of creation, (2) the existence of an implicit inner division of labor, and (3) the adoption of different strategies and repertoires.

In terms of timing, it is possible to differentiate between newcomers and long-standing organizations: to the first belong groups that have acquired relevance in the heat of the turmoil unleashed by the HSP (Foro Español de la Familia -Foro-, set up in 1999, and Hazte Oír -HO- created in 2001), whereas the second one embraces older organizations such as Concapa (created as early as 1929) and Camino Neocatecumenal (set up in 1964 Regarding "thematic specialization," a distinction between pro-life groups (HO, Right to Life ...), family-oriented groups that have opposed samesex marriage (Foro...), education-oriented groups (Concapa), and pastoral groups (Camino Neocatecumenal, Obra de María, Opus Dei, Comunión y Liberación) might be established. This distinction does not preclude the fact that many of them have jointly participated in the same campaigns. As far as strategic differences are concerned, organizations could be classified along a radical vs. conventional continuum. The rivalry between Foro and $\mathrm{HO}$ is the best example of this difference and has paved the way for the decision of the latter to leave the Foro in October 2009. Even though this decision has been officially framed in terms of organizational discrepancies, the contrast between the radical and outspoken approach of $\mathrm{HO}$ and the 
more conventional outlook of Foro might be a more relevant reason for inner frictions. HO, a group made up of young people whose President relies heavily on new information technologies as tools for Christianoriented political action, does not shy away from openly attacking PP leadership (Rajoy being its main target) because of its allegedly dubious stance in relation to abortion; in contrast, the Foro, whose main representative was Secretary of State under the PP government (1996-2004), adopts a rather non-aggressive and cautious approach. All these differences do not permit to hastily talk about the unity and cohesion of a so-called "Catholic bloc", as some scholars have done. ${ }^{12}$

All in all, total membership (also considering Legionarios de Cristo, established in 1941) would amount to approximately 4,500,000-5,000,000 members (own estimation based on Sánchez-Vallejo, 2009; www.redescristianas.net, and other web pages). Overlapping membership is frequent though (Concapa belongs to the Foro, for instance, and HO claims to have Opus Dei and Legionarios de Cristo members in their rank-and-file), thus making the accurate estimation of members a difficult endeavour. ${ }^{13}$

\subsection{Political Alliances: Do Christian-Democratic Parties Exist?}

"During the 1980s, political and social leaders renounced to incorporate religious conflicts into their political agenda ... Over the last 15 years, however, these criteria are intervening in the political debate insofar as political elites want to obtain electoral benefits by addressing the religious identities of their voters." Although "the total number of religious voters has been decreasing over time, it is easier to find voters who use religiosity to base their support to conservative parties than the opposite situation" (Calvo, Martínez, and Montero 2010, 4, 8, 10).

At present, the most important Christian-oriented parties are the PP and the regionally-based Partido Nacionalista Vasco (Basque Nationalist PartyPNV) and UDC (the coalition partner of the Catalan nationalist group CiU). Not all of them define themselves in the same way though: the PP refers to itself as a "centrist political formation," which adheres to the Spanish liberal tradition, the PNV recognizes its "non-confessional and humanist" nature, and only UDC acknowledges explicitly its "Christian-Democratic inspiration" (www.pp.es; www.eaj-pnv.eu; www.unio.org). In the fight against HSP, the SCC has found uneven support in them. Parliamentary voting shows nonetheless tight results in relation to the same-sex marriage reform (187/147, all the PP representatives except one, four from UDC and 
some from the PNV voted against it), and the abortion law (184/158, the PP, UPN -Union of the People of Navarre-, CC -Canarias Coalition- and seven members from $\mathrm{CiU}$, three belonging to $\mathrm{CDC}$-Convergencia Democratica de Catalunya- and four to UDC voted against the law).

The alliance between clerical and political forces has proceeded along different stages: (1) the SCC has expressed its political views before elections and has warned Catholics against voting for those parties whose programmers run counter Christian values; by doing so, the church has implicitly supported (without endorsing) Christian-oriented parties; (2) if electoral results run counter SCC interests, the church turns its eyes to those parties sympathetic to religious' views -despite non-existent explicit links with those actors; (3) if the parliamentary process goes against SCC interests and HSP get eventually approved, the church will resort to those political forces that have voted against them (mobilization and public pressure might have also taken place before the HSP got approved).

As regards the same-sex reform, the PP has resorted to the Constitutional Court in order to assess its alleged un-constitutionality and seems to be internally divided about the abortion law: while its leader (Rajoy) and some of his closest acolytes (Saénz, Cospedal) are confident that the Constitutional Court will "do the party's job" by declaring the law unconstitutional, the hard-liners (Mayor Oreja, Aguirre, Trillo) have declared in various ways that the PP will repel the law if it accedes to power in November 2011. The problem is that the PP does not want to be perceived as an uncritical supporter of the SCC for this could mobilize a traditionally abstentionist left-wing electorate, nor is it interested in antagonizing its centrist social bases. The abortion law has also created tension within the PNV: in the pro-life demonstration in Bilbao on May 7, which summoned around 5,000 people (according to HO.org), individual PNV and PP representatives were seen, but the cadres of the Basque Party were absent. As a matter of fact, the promoters of the association Family and Human Dignity, created in 2008 to fight against same-sex marriage and the abortion law, have been parliamentary members of PP and CiU (not the PNV).

\subsection{Mobilization Strategies of the SCC: The Alliance with Social and Political Forces}

In order to attack HSP the SCC has chosen an adversarial strategy reflected in a broad array of techniques: from the organization of press 
conferences to the support (and sometimes promotion) of mobilizing events. The SCC repertoire has thus broadened: when pressure and lobby strategies fail, the Church can count on its social and political allies in order to take people to the streets. However, mobilization does not preclude the simultaneous use of conventional techniques associated with the exercise of pressure on the legislative and judiciary powers. The new SCC strategy "is organized around two main elements ... in the first place, the explicit linking with political and social organizations which, in an effective way, become the executors of church strategies and priorities ... in the political realm, the church has strengthened its public adherence to conservative political parties, [secondly], on account of the formalization of new alliances, the church has had an easier access to new arenas of conflict with the government" (Calvo, Martínez and Montero, 2010 15-17). Most SCC-supported demonstrations have not been directly organized by the Church itself (nor by the PP), but by lay Christian-inspired social groups: the hierarchy of the Church has visibly taken part in some rallies whereas, on other occasions, clerical figures have explicitly announced that "no bishops will participate" (as the Cardinal Valera stated in relation to the anti-abortion protest on October 17, 2009). The organizing social groups have frequently stressed that these contentious events are "civil demonstrations" and have assured that "no endorsement from political parties or religious denominations are admitted." The SCC and the PP have nonetheless provided these contentious events with strategic support and clerical and political representatives.

Although mobilization has taken place in many different Spanish cities, Madrid has become the main site of Catholic-inspired protest events. As regards the fight against same-sex marriage and abortion, a distinction between collective actions on the whole and protests events are introduced, the latter being a subcategory that refers to contentious events on the street. ${ }^{14}$

\section{CONCLUSIONS}

Ethical issues, such as abortion liberalization and same-sex marriage, are being contested by religiously-inspired lay groups, advocacy coalitions and churches in Europe. Mobilization against these reforms is not surprising in democracy, but the political role that churches might play in the protest is however not so easy to foresee. In Spain, this type of 
protest has occurred under Zapatero's Socialist rule (2004-2011) and has been characterized by the visible presence of the SCC which, in alliance with social and partisan forces, has acted as a political contender. Unlike other European churches that have refrained from belligerently entering politics, the SCC has invested, firstly, significant resources in the launching of campaigns against Socialist-promoted reforms and has helped, later on, to mobilize the most Conservative social quarters against them. Even though there might be exogenous reasons for this adversarial strategy, endogenous reasons ought to be stressed: the predominant position of an extraordinarily well-endowed Church in a society which still defines itself as mainly Catholic; the ever-present privileged church-state relationship; the room for maneuver that religious leaders enjoy under a (constitutionally-defined as) non-confessional state; and the existence of important social and political allies are reasons to be borne in mind. The new Socialist agenda, which puts the emphasis on morally-liberal reforms, has also paved the way to the utilization by the church of the "sociological argument": the idea that Spanish national identity is inextricably linked to Catholicism has thereby provided the SCC with the "necessary legitimacy" to play an adversarial role. This new conflictive scenario has been facilitated by the activation of religious voting which has been occurring since the mid 90s. A similar situation can be found in other homogeneous religious markets where national identity and Catholicism have been historically and deeply connected (Italy and Poland). However, in other countries characterized by the same market conditions, the $\mathrm{CC}$ has adopted a more nuanced position: in Portugal, for instance, religious voting is absent because the main political parties do not show major differences in ethical issues, while in France the strong laic tradition impairs the adoption of a visibly public role by the church. The peculiar combination of the factors analyzed helps understand why the SCC is a rather distinctive but not entirely unique political actor. Yet what is unusual about this case is the fact that the church's political assertiveness unfolds in a social context which, comparatively speaking, has experienced fast and increasing secularization.

\section{NOTES}

1. This heading draws upon the title of the monograph, Church and State in Contemporary Europe: The Chimera of Neutrality, in West European Politics, January 1, 2003. 
2. I am most grateful to the editors of Religion and Politics, Sabrina Ramet and Ted Jelen, for having drawn my attention to the quasi end of establishment in the Nordic region.

3. Catholics reach the highest peak $(45 \%)$ - only to be surpassed by Muslims $(60 \%)$ - when advocating that abortion "is never justified" (Norris and Inglehart 2004, 174).

4. For a succinct, yet highly informative, account of the SCC in Spanish history see Casanova (1994, 75-81) and Pérez-Agote (2008a, 87-118).

5. There have been scholars who have also considered the SCC an interest group or a lobby but have ascribed to it, oddly enough, opposite political capacities: too much/too little power and influence (Requena 2005, 335; Gurrutxaga 2008, 67; Pérez-Agote 2008b, 126). Discrepancy can be explained by the absence of thorough empirical analyses of the SCC as an interest group.

6. http://www.laicitat.org.

7. The SEC structure can be seen in Figure 1 (see online supplemental material).

8. http://6865.blogcindario.com/2007/11/04483-la-iglesia-catolica-en-espana-noviembre-de-2007campana-de-comunicacion.html.

9. Equally important is the SCC presence in the mass media industry (see Table 1 (online supplemental material)).

10. At the summit of its power, the Italian CC could boast about having one priest per 861 inhabitants in the "white" Northern regions in 1947 (Warner 2000, 46-47). However, the highest ratio in the Western world was reached in Quebec around 1950, with one priest per 504 inhabitants (Eller 1999, 318).

11. For those alliances to take place HSP have to encapsulate important issues not only for the church but also for significant social sectors, in the sense that they must show some interest (saliency) and be divided about them (skewness), while political parties must offer different alternatives as to how to tackle them (differentiation) (Norris 1997, 80).

12. "The Catholic bloc advocates a unitary project ... and is made up of four sectors: organic intellectuals belonging to the hierarchy ...; organizers of Catholic masses (Concapa, Camino Neocatecumenal ...); mass media (COPE, Abc, La Razón...); Catholic-inspired political parties (Díaz-Salazar 2008, 141).

13. According to Catholic associations and their sponsored web pages, membership can be broken down as seen in Table 2 (online supplemental material).

14. I am grateful to Juan Sevilla for having helped me collect information on this point. As it usually happens when gathering data about participants in demonstrations, discrepancies in numbers between the promoters (and like-minded newspapers) and other sources can be immense. For this reason, the choice of the arithmetic mean to present numbers can be obviously disputed. Protest events have been classified as big (over 500,000 participants), medium-sized $(50,000-500,000)$ and small (50,000 or less). For further description, see Tables 3 and 4 and Figures 2 and 3 (online supplemental material).

\section{REFERENCES}

Aldridge, Alan. 2000. Religion in the Contemporary World. Cambridge: Polity Press.

Anderson, John. 2003. "Catholicism and Democratic Consolidation in Spain and Poland." West European Politics, January 1.

Barreiro, Belén. 2000. Democracia y Conflicto Moral: La Política del Aborto en España e Italia (English translation). Madrid: Istmo.

Basque Nationalist Party (Partido Nacionalista Vasco). 2009. "Title of article." http://www. eaj-pnv.eu/eusk/ (Accessed on May 3, 2009).

Berry, Jeffrey M. 1997. The Interest Group Society. New York, NY: Longman.

Botterman, Sarah, and Marc Hooghe. 2009. "The Christian Democratic Vote and Religious Belonging." Presented at the ECPR General Conference on Ideology, Religiosity and Voting, Postdam.

Byrnes, Timothy A. 2006. "The Polish Church: Catholic Hierarchy and Polish Politics." In The Catholic Church and the Nation-State, eds., Manuel Paul C., Lawrence C. Reardon, and Clyde Wilcox. Washington, DC: Georgetown University Press. 
Calvo, Kerman, Álvaro Martínez, y José Ramón Montero. 2010. “Devotos y Votantes: El Peso del Factor Religioso en las Elecciones Generales (English translation)."

Casanova, José. 1994. Public Religions in the Modern World. Chicago, IL: The University of Chicago Press.

Democratic Alliance of Catalonia (Unio Democratica de Catalunya). 2009. "Article title." http://www.unio.es/ (Accessed on May 3, 2009).

Díaz-Salazar, Rafael. 2008. "Institución religiosa y democracia en España (English translation)." En Religión y Política en la Sociedad Actual (English translation), eds., Pérez-Agote A., y J. Santiago. Madrid: Universidad Complutense de Madrid: Centro de Investigaciones Sociológicas.

Eller, J. D. 1999. "Quebec: Masters in Our Own House." From Culture to Ethnicity to Conflict, ed., In Eller, J.D. Ann Arbor: The University of Michigan Press.

Elzo, Javier. 2000. Jóvenes 2000 y Religión (English translation). Albarracin: Fundación Santa María.

Elzo, Javier. 2008. "La evolución socio-religiosa en España en los últimos 30 años: una aproximación empírica, en Bericat Eduardo (coord.) El Fenómeno Religioso (English translation)." Presencia de la Religión y de la Religiosidad en las Sociedades Avanzadas(English translation). Sevilla: Fundación Centro de Estudios Andaluces.

Enyedi, Zsolt. 2003. "Emerging Issues in the Study of Church-State Relations." West European Politics, January 1.

Esteban, Valeriano. 2008. "La secularización en entredicho: la revisión de un debate clásico de la sociología (English translation)." En Religión y Política en la Sociedad Actual (English translation), eds., Pérez-Agote A., y J. Santiago. Madrid: Universidad Complutense de Madrid: Centro de Investigaciones Sociológicas.

Fundación Santa María. 2000., Jóvenes 2000 y Relgión. Madrid: Grupo SM.

González-Anleo, Juan. 2008. "El Post-Católico Español y el Pluralismo Religioso.” In El Escepticismo Religioso y Secular en Europa, ed. Bericat, Eduardo. Sevilla: Centro de Estudios Andaluces.

Gurrutxaga Abad, Ander. 2008. "La Institución Lobby: La Religión en la Política (English translation)." En Religión y Política en la Sociedad Actual (English translation), PérezAgote A., y J. Santiago. Madrid: Universidad Complutense de Madrid: Centro de Investigaciones Sociológicas.

Huneeus, Carlos. 1985. La Unión de Centro Democrático y la Transición a la Democracia en España (English translation). Madrid: Centro de Investigaciones Sociológicas.

Lipset, Seymour M., and Stein Rokan. 1967. Party Systems and Voter Alignments. New York, NY: The Free Press.

Luckmann, Thomas. 1973. La Religión Invisible (English translation). Salamanca: Ediciones Sígueme.

Madeley, John T.S. 2003a. "A Framework for the Comparative Analysis of Church-State Relations in Europe." West European Politics, January 1.

Madeley, John T.S. 2003b. "A Framework for the Comparative Analysis of Church-State Relations in Europe." West European Politics, January 1.

Martín, Irene, and Yannis Tsirbas. 2009. "The Church, Moral Issues and Socialist Governments in Greece and Spain." Presented at the ECPR General Conference on Ideology, Religiosity and Voting, Postdam.

Minkenberg, Michael. 2003. "The Policy Impact of Church-State Relations: Family Policy and Abortion in Britain, France, and Germany." West European Politics, January 1.

Montero, José Ramón, Kerman Calvo, and Alvaro Martínez. 2008. "El Voto Religioso en España y Portugal (English translation)." Revista Internacional de Sociología 66:19-54. 
Norris, Pippa. 1997. Electoral Change since 1945. Cambridge: Blackwell.

Norris, Pipa, and Ronald Inglehart. 2004. Sacred and Secular: Religion and Politics Worldwide. Cambridge: Cambridge University Press.

Parkes, Geneviève. 1999. "Redefining the Legitimacy of Anti-abortion Pressure Groups in Europe, Looking at France, Britain and Central Europe." Journal of Social Welfare and Family Law 21:285-294.

Pérez-Agote, Alfonso, and José A. Santiago García. 2005. "La Situación de la Religión en España a Principios del Siglo XXI. Madrid (English translation)." Opiniones y Actitudes 49:49-50.

Pérez-Agote, Alfonso, 2008a. "Altar y Trono: Sociología Histórica de las Relaciones Iglesia-Estado en España (English translation)." En Religión y Política en la Sociedad Actual (English translation), eds., Pérez-Agote A., y J. Santiago. Madrid, UCM y CIS.

Pérez-Agote, Alfonso. 2008b. "La Secularización de los Españoles (English transation)." En Religión y Política en la Sociedad Actual, eds., Pérez-Agote A., y J. Santiago. Madrid: Universidad Complutense de Madrid, Centro de Investigaciones Sociológicas.

Pérez-Nievas, Santiago, y Guillermo Cordero. 2011. "Religious Change in Europe (19802008)." Presented at the SISP Annual Conference, Venice.

Popular Party (Partido Popular). 2009. "Title of article." http://www.pp.es/ (Accessed on May 3, 2009.

Ramet, Sabrina P. 2007. The Liberal Project and the Transformation of Democracy. Houston: Texas A\&M University Press.

Requena, Miguel. 2005. "Religión y Sociedad: la Secularización de la Sociedad Española (English translation)." In Tres Décadas de Cambio Social en España (English translation), eds., González Juan Jesús, y Miguel Requena. Madrid: Alianza Editorial.

Rinaldi, Ferruccio, Paolo Segatti, y Cristiano Vezzoni. 2010. "Italy: Religion and Politics." mimeo.

Sánchez-Vallejo, M.A. 2009. "Los Nuevos Ejércitos del Papa en España (English translation)." www.redescristianas.et (Accessed on ???).

Santiago García, Jose A. 2008 "Dimensión Consecuencial y Estructura Social de la Vida Religiosa en España." En Religión y Política en la Sociedad Actual, eds., Pérez-Agote A., y J. Santiago. Madrid: UCM y CIS.

Spanish Center for Sociological Research (Centro de Investigaciones Sociológicas). 2009. http://www.cis.es/cis/opencms/ES/index.html (Accessed on April 18, 2009).

Vidal Bonifaz, Francisco. "Burillo y los Medios Católicos." In La Rueda de la Fortuna. ruedadelafortuna.wordpress.com (Accessed on March 17, 2010).

Warner, Carolyn M. 2000 Confessions of an Interest Group. Princeton, NJ: Princeton University Press. 